\title{
Correction to: Monitoring and Predicting Saltwater Intrusion via Temporal Aquifer Vulnerability Maps and Surrogate Models
}

\author{
Fatemeh Faal $^{1}$ (D) $\cdot$ Hamid Reza Ghafouri $^{1}$ (D) $\cdot$ Seyed Mohammad Ashrafi ${ }^{1}$
}

Published online: 29 January 2022

(c) Springer Nature B.V. 2022

\section{Correction to: Water Resour Manag https://doi.org/10.1007/s11269-021-02970-9}

In Table 1 of this article, the data in columns 4 and 5 were mistakenly listed and in the abbreviations section, 2 in R2 must be in superscript format. Also, in equation 5, the radical must cover the entire right side of the equation. The corrected Table 1 is shown in the next page and the correct equation 5 is shown below. The original article has been corrected.

$$
R M S E=\sqrt{\frac{1}{N} \sum_{i=1}^{N}\left(y_{i}-\hat{y}_{i}\right)^{2}}
$$

The online version of the original article can be found at https://doi.org/10.1007/s11269-021-02970-9.

Fatemeh Faal

f-faal@phdstu.scu.ac.ir; faalfateme@gmail.com

1 Department of Civil Engineering, Faculty of Civil Engineering and Architecture, Shahid Chamran, University of Ahvaz, Ahvaz, Iran 
Table 1 Ranges and ratings of GALDIT method parameters

\begin{tabular}{|c|c|c|c|c|c|}
\hline Factor & Weight/Rating & 2.5 & 5 & 7.5 & 10 \\
\hline Groundwater occurrence & 1 & $\begin{array}{r}\text { Bounded } \\
\text { aquifer }\end{array}$ & $\begin{array}{l}\text { Leaky confined } \\
\text { aquifer }\end{array}$ & $\begin{array}{l}\text { Unconfined } \\
\text { aquifer }\end{array}$ & $\begin{array}{r}\text { Confined } \\
\text { aquifer }\end{array}$ \\
\hline $\begin{array}{l}\text { Aquifer hydraulic conductivity (m/ } \\
\text { day) }\end{array}$ & 3 & $<5$ & $5-10$ & $10-40$ & $>40$ \\
\hline $\begin{array}{l}\text { Level of groundwater above the } \\
\text { sea }(\mathrm{m})\end{array}$ & 4 & $>2$ & $1.5-2$ & $1-1.5$ & $<1$ \\
\hline Distance from shoreline (m) & 4 & $>1,000$ & $750-1,000$ & $500-750$ & $<500$ \\
\hline $\begin{array}{l}\text { Impact of the existing status of } \\
\text { SWI: TDS }(\mathrm{g} / \mathrm{L})\end{array}$ & 1 & $<1$ & $1-3$ & $3-10$ & $>10$ \\
\hline Thickness of aquifer (m) & 2 & $<5$ & $5-7.5$ & $7.5-10$ & $>10$ \\
\hline
\end{tabular}

Publisher's Note Springer Nature remains neutral with regard to jurisdictional claims in published maps and institutional affiliations. 